\title{
REVIEW
}

\section{Skeletal sexual dimorphism: relative contribution of sex steroids, GH-IGF1, and mechanical loading}

\author{
Filip Callewaert, Mieke Sinnesael, Evelien Gielen, Steven Boonen and Dirk Vanderschueren \\ Center for Musculoskeletal Research, Department of Experimental Medicine, Katholieke Universiteit Leuven, Herestraat 49, \\ B-3000 Leuven, Belgium \\ (Correspondence should be addressed to D Vanderschueren; Email: dirk.vanderderschueren@uz.kuleuven.be)
}

\begin{abstract}
Structural gender differences in bone mass - characterized by wider but not thicker bones - are generally attributed to opposing sex steroid actions in men and women. Recent findings have redefined the traditional concept of sex hormones as the main regulators of skeletal sexual dimorphism. GH-IGF1 action is likely to be the most important determinant of sex differences in bone mass. Estrogens limit periosteal bone expansion but stimulate endosteal bone apposition in females, whereas androgens stimulate radial bone expansion in males. Androgens not only act directly on bone through the androgen receptor (AR) but also activate estrogen receptor $\alpha$ or $-\beta$ (ER $\alpha$ or ER $\beta)$ following aromatization into estrogens. Both the AR and ER $\alpha$ pathways are needed to optimize radial cortical bone expansion,
\end{abstract}

whereas AR signaling alone is the dominant pathway for normal male trabecular bone development. Estrogen/ER $\alpha$ mediated effects in males may - at least partly - depend on interaction with IGF1. In addition, sex hormones and their receptors have an impact on the mechanical sensitivity of the growing skeleton. AR and ER $\beta$ signaling may limit the osteogenic response to loading in males and females respectively, while ER $\alpha$ may stimulate the response of bone to mechanical stimulation in the female skeleton. Overall, current evidence suggests that skeletal sexual dimorphism is not just the end result of differences in sex steroid secretion between the sexes, but depends on gender differences in GH-IGF1 and mechanical sensitivity to loading as well.

Journal of Endocrinology (2010) 207, 127-134

\section{Introduction}

Sex steroids are mainly synthesized by the gonads (testis and ovary), but the adrenals constitute an additional source (Vanderschueren et al. 2004, Callewaert et al. 2010a). Sex steroids are involved in the regulation of a number of important physiological processes, including sexual differentiation of the genitalia, sexual maturation, and reproduction. Sex hormones also have an impact on skeletal homeostasis, because they add bone during puberty and subsequently maintain skeletal integrity, both in men and women (Riggs et al. 2002). However, gender differences in bone growth become apparent during puberty, with men reaching higher peak bone mass, greater bone size, and, ultimately, a stronger skeleton compared to women (Garn 1970, Seeman 2001). Puberty builds a bigger, but not a denser, skeleton in males, as bone mineral acquisition in long bones occurs in proportion to the volume of the bone (Zamberlan et al. 1996). As a result, the volumetric bone mineral density (BMD) does not differ between men and women. In addition, growth during puberty also builds wider and slightly taller vertebral bodies in men, without sex differences in trabecular BMD (Gilsanz et al. 1994). As a result of these stronger structural features achieved during growth, the male skeleton is less susceptible to osteoporosis later in life (Seeman 2002). Although fewer men than women sustain fractures during aging, fragility fractures are common in men and are associated with a significant burden in terms of morbidity, mortality, and economic cost to the community (Boonen et al. 2007, Khosla et al. 2008). Therefore, more insight into the mechanisms involved in bone mass acquisition is essential to improve our understanding of the pathophysiology of osteoporosis and osteoporotic fracture risk in men.

Skeletal gender differences in radial bone growth (skeletal sexual dimorphism) are traditionally attributed to stimulatory 'male' androgen action as opposed to inhibitory 'female' estrogen action on periosteal bone formation. However, particularly in men, the mechanism of action of sex steroids on bone growth appears considerably more complex. Testosterone, the main circulating androgen in males, not only activates the androgen receptor (AR) but also acts on the estrogen receptor- $\alpha$ or $-\beta$ (ER $\alpha$ or $E R \beta)$ following 
aromatization into $17 \beta$-estradiol $\left(\mathrm{E}_{2}\right.$; Vanderschueren et al. 2004, Callewaert et al. 2010a). Experiments in animals as well as in a number of case reports of men with either a loss-of-function mutation in ER $\alpha$ or an aromatase deficiency provided evidence that estrogens play a key role in male skeletal homeostasis (Smith et al. 1994, 2008, Vanderschueren et al. 1997, Vidal et al. 2000, Bouillon et al. 2004, Rochira et al. 2007). In addition to sex steroids, other hormones such as $\mathrm{GH}$ and insulin-like growth factor 1 (IGF1) may further contribute to the development of the skeletal sexual dimorphism. GH and IGF1 - the GH-IGF1 axis - are both primarily responsible for postnatal growth (Lupu et al. 2001). Moreover, sex steroids and the GH-IGF1 axis interact closely during puberty (Mauras et al. 1996), optimizing bone mass acquisition during pubertal growth. Finally, skeletal growth is further stimulated by mechanical loading (Frost 2003), which in turn may be influenced by sex hormones as well. In fact, mechanical loading increases bone formation in close association with estrogen signaling, at least in female mice (Lee et al. 2003). Thus, sex steroids, IGF1, and mechanical stimuli may both independently and mutually affect the acquisition of an optimal bone mass during puberty. In this review, three major questions will be addressed: 1) to what extent do sex steroids or GH-IGF1 or both influence the skeletal gender differences; 2) what is the relative importance of $A R$ and $E R \alpha$ signaling in the acquisition of male cortical and trabecular bone mass; and 3) do sex steroids and their receptors affect the adaptive response of bone to loading?

\section{Hormonal factors involved in the development of the skeletal sexual dimorphism}

\section{Evidence for a role of androgens and estrogens}

Puberty represents a critical growth period during which important gender differences in bone width and strength are established. In fact, boys develop a larger periosteal perimeter than girls from mid-puberty onward (Seeman 2001, Kirmani et al. 2009). In contrast, girls experience less periosteal expansion but more endocortical apposition compared to boys. As a result, men not only build up wider bones but also stronger bones, with cortical bone further away from the neutral axis of the long bone and more resistant to bending. Sex hormones have traditionally been considered the primary mediator of skeletal sexual dimorphism in bone size and strength. This prevailing opinion was established by the observation of a reduced periosteal perimeter in orchidectomized growing male rats versus an increased periosteal circumference in ovariectomized female rats (Turner et al. 1990). This landmark study led to the assumption that androgens were stimulatory and estrogens inhibitory for male and female radial bone growth respectively. In line with this concept, a study in pubertal mouse models showed that androgen withdrawal, as induced by orchidectomy, decreases radial bone expansion in males (Callewaert et al. 2010b). Ovariectomy, on the other hand, increases radial bone growth in females (Callewaert et al. 2010b). However, these hormonal effects differ in their timing of action, as the androgenmediated effects occur only during later stages of puberty, compared with the earlier effect of estrogens and are in line with the traditional concept that androgens stimulate male bone size whereas estrogens limit female bone size. However, recent findings have partly redefined this concept, with a significant body of evidence pointing to a role of estrogen action in males as well. In male mice, estrogen deficiency on top of androgen withdrawal further reduces radial bone expansion, at least during the early stages of puberty (Callewaert et al. 2010b), in line with the concept that aromatization of androgens into estrogens also contributes to the skeletal gender differences (Fig. 1).

\section{Evidence for a critical role of GH-IGF1}

Other hormones such as GH and IGF1 also manifestly increase during puberty and are regarded as critical regulators of pubertal bone growth as well (Mauras et al. 1996). Importantly, GH-IGF1 action even appears to be the most important determinant of gender differences in bone mass in pubertal mice (Callewaert et al. 2010b). IGF1 levels are indeed higher in male versus female mice during early puberty, the time window during which most of the gender differences are established. Moreover, mice with a disrupted $\mathrm{GH}$ receptor (GHR) - associated with extremely low IGF1 levels - also have a severely reduced radial bone expansion without gender differences in radial bone growth (Callewaert et al. 2010b). Earlier observations of severe growth retardation in mice lacking GHR, IGF1, or both support the crucial role of GH and IGF1 in the control of postnatal bone growth (Lupu et al. 2001; Fig. 1). Human and animal studies agree with this concept, as IGF1 treatment in GHR knockout (KO) mice or patients with $\mathrm{GH}$ resistance stimulates growth or even reverses the detrimental effects of GHR deficiency (Laron 1999, Sims et al. 2000). Beside this direct action of GH/IGF1, however, there is also ample evidence for an interacting role of sex steroids and IGF1. For instance, the pubertal increase in GH-IGF1 appears to be mediated by the sex steroids. Neonatal testosterone secretion establishes the GH secretion pattern, which, in turn, also determines masculinization of hepatic steroid metabolism (Jansson et al. 1985). In addition, perinatal androgens appear to be a key determinant of adult bone length in males, as shown by the lower femoral and tibial length in androgen-deficient hypogonadal mice compared with age-matched orchidectomized mice (Sims et al. 2006). In addition, it is now well established, both in humans and animals, that estrogens may interact with the GH-IGF1 axis (Juul 2001, Venken et al. 2005). In fact, estrogen-related changes in male bone mass seem to be IGF1-dependent. In male mice, estrogen-dependent skeletal changes are associated with lower IGF1 levels during early puberty. Similar findings have been reported in ER $\alpha \mathrm{KO}$ mice and male rats treated with an aromatase inhibitor (Vanderschueren et al. 1997, Vidal et al. 2000). Likewise, aromatase inhibition in 


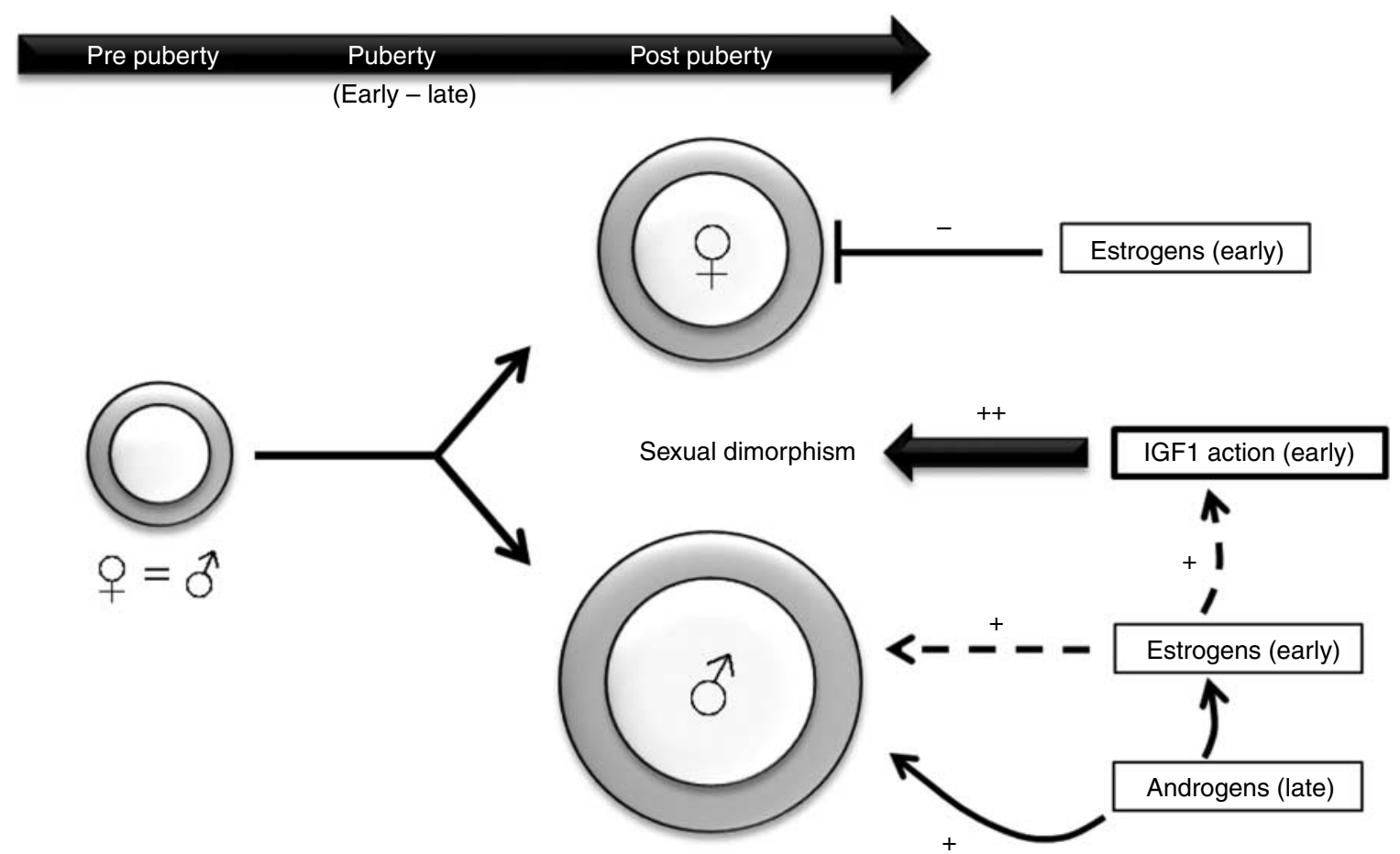

Figure 1 Insulin-like growth factor 1 (IGF1) is the primary determinant of the skeletal sexual dimorphism, which develops during puberty. Male androgen action also contributes to the larger male bone size by stimulating radial bone expansion mostly during late puberty. Male estrogen action has early stimulatory effects on periosteal bone expansion, but may be regulated through changes in IGF1 levels. In female mice, estrogens limit radial bone expansion during early puberty.

adolescent boys decreases estrogen levels and is associated with a concomitant reduction in IGF1 levels (Mauras et al. 2000). Moreover, a recent study in cartilage-specific ER $\alpha$ KO mice showed that low $\mathrm{E}_{2}$ levels during early skeletal maturation stimulate longitudinal bone growth through actions on the GH-IGF1 axis, independent of ER $\alpha$ in growth plate cartilage (Borjesson et al. 2010). Collectively, a significant body of evidence identifies GH/IGF1 as a critical regulator of skeletal gender differences. Nevertheless, the notion that sex steroids may interact with IGF1 suggests that the androgens and estrogens may indirectly affect the skeletal sexual dimorphism as well, through interaction with GH-IGF1 (Fig. 1).

Overall, the development of skeletal sexual dimorphism in mice resembles the human situation, since most of the gender differences in bone mass are established during puberty and associated with similar hormonal changes (Fig. 1). Nevertheless, some differences become apparent as well. In humans, it is generally accepted that sex differences in bone morphology are the result of the earlier onset of puberty in girls and the longer duration of puberty in boys, without major differences in absolute growth rate between sexes (Seeman 2002, Iuliano-Burns et al. 2009). In mice, on the other hand, absolute gender differences in periosteal and endocortical bone formation also contribute to the development of the skeletal sexual dimorphism (Callewaert et al. 2010b). In fact, periosteal and endosteal bone formation rates, as determined by dynamic histomorphometry, are higher and lower respectively in male versus female mice. Obviously, similar information on dynamic bone formation rates in humans is not available. Differences with respect to pubertal GH-IGF1 secretion may exist between humans and mice as well. In contrast to mice, peak IGF1 levels are not different between boys and girls. However, girls have an earlier IGF1 peak associated with the earlier onset of puberty (Leger $e t$ al. 2007). Overall, extrapolation of mice data on hormonal determinants of skeletal sexual dimorphism to the human condition should be handled with caution.

\section{Relative importance of androgens and estrogens during male bone growth}

It has become increasingly clear that androgen signaling in males is far more complex than originally anticipated. A significant body of evidence in humans and animals has now firmly established that at least part of the androgen-mediated bone growth in males may be mediated through conversion of androgens into estrogens and subsequent $\mathrm{ER} \alpha$ activation. In fact, aromatase-deficient men, estrogen-resistant men, as well as transgenic mice lacking the aromatase or $E R \alpha$ gene all present with low bone mass (Vidal et al. 2000, Miyaura et al. 2001, Bouillon et al. 2004, Rochira et al. 2007, 
Smith et al. 2008). Together, these findings support the view that estrogens are indispensable for male skeletal health. Nevertheless, more conclusive evidence on the relative importance and differential roles of AR and ER $\alpha$ in cortical and trabecular bone mass accrual and maintenance was only recently provided by the longitudinal evaluation of male mice lacking both AR and ER $\alpha$ (Callewaert et al. 2009). This study supports AR activation as being solely responsible for the development and maintenance of male trabecular bone mass, since AR inactivation - in the presence or absence of $\mathrm{ER} \alpha$ - results in a severely reduced trabecular bone mass with increased bone turnover (Callewaert et al. 2009). Similar changes (also described in other ARKO models; Kawano et al. 2003, Venken et al. 2006) are the main features of hypogonadal osteoporosis as well (Finkelstein et al. 1989). Along the same line, testosterone treatment restores orchidectomy-induced trabecular bone loss in male mice (Venken et al. 2006), adding further evidence to the concept of AR signaling as a critical regulator of the development of normal male trabecular bone mass. On the other hand, administration of an aromatase inhibitor in ARKO and orchidectomized mice has no effect on trabecular bone (Venken et al. 2006), suggesting that residual $\mathrm{ER} \alpha$ activation fails to restore or compensate AR-mediated bone loss. This lack of a role of ER $\alpha$ during male trabecular bone growth sharply contrasts to the important role of $E R \alpha$ in female mice (Lindberg et al. 2001), or with the pharmacological effect of (supraphysiological) estrogen administration in orchidectomized male mice (Vandenput et al. 2001). Moreover, various studies even report an increased trabecular bone mass in $\mathrm{ER} \alpha \mathrm{KO}$ mice (Vandenput et al. 2001, Sims et al. 2003, Callewaert et al. 2009), which could be attributed to higher androgen levels acting through the AR. In line with this assumption, surgical castration or anti-androgen treatment of $\mathrm{ER} \alpha \mathrm{KO}$ mice normalizes the trabecular bone mass in these mice (Vandenput et al. 2001, Sims et al. 2003). Together, these observations clearly define AR and ER $\alpha$ activation as the primary determinant of trabecular bone development in male and female mice respectively.

In contrast to their role in trabecular bone, $\mathrm{AR}$ and $\mathrm{ER} \alpha$ are both required for optimal stimulation of male cortical bone mass in male mice. In fact, $\mathrm{AR}-\mathrm{ER} \alpha$ 'double' KO mice have lower cortical bone mass compared with either ARKO or ER $\alpha$ KO mice alone (Callewaert et al. 2009). Likewise, administration of an aromatase inhibitor further reduces cortical bone mass in orchidectomized mice (Callewaert et al. $2010 b$ ). In line with these findings, testosterone action on periosteal bone formation and cortical thickness is blunted by an aromatase inhibitor in orchidectomized mice (Venken et al. 2006). The importance of aromatization of androgens into estrogens for cortical bone expansion is also supported by observations in humans. Cortical bone dimensions failed to enlarge in an adolescent aromatase-deficient boy despite supranormal testosterone concentrations (Bouillon et al. 2004). In this patient, estrogen treatment substantially increased bone size, suggesting that optimal cortical bone expansion requires activation of both $\mathrm{AR}$ and $\mathrm{ER} \alpha$, not only in mice but also in humans. Beside ER $\alpha$, estrogens might also activate ER $\beta$. In contrast to female ER $\beta K O$ mice - which showed an increased cortical bone mineral content and crosssectional area - ER $\beta$ does not appear to play any role in male skeletal growth, since male ER $\beta K O$ do not display a bone phenotype (Windahl et al. 1999, Vidal et al. 2000, Sims et al. 2002). Thus, ER $\alpha$ but not ER $\beta$ appears to mediate estrogen actions during male skeletal growth. Although AR activation is the dominant pathway of androgen signaling for male trabecular bone growth and maintenance, it would seem therefore that $\mathrm{AR}$ and $\mathrm{ER} \alpha$ activation are both required to optimize cortical bone growth (Fig. 2).

\section{Androgen signaling and the mechanical sensitivity of the male skeleton}

\section{Functional response of bone to loading}

Mechanical loading has a major impact on skeletal growth. The change in the body weight and the resulting mechanical stimulation of the skeleton during puberty are substantial. Since overall growth rate is higher in males than females, the male skeleton encounters higher mechanical demands. It is therefore tempting to speculate that this higher load bearing in males also stimulates bone growth to a greater extent than in females, as reflected by more periosteal bone formation during puberty (Callewaert et al. 2010b). The stimulatory role of mechanical loading and physical activity on bone expansion has been well documented in numerous experimental and clinical studies. A range of noninvasive axial loading models, using various animal models subjected to different exercise regimens, have provided insights into the anabolic response of bone to loading (Mosley et al. 1997, Mosley \& Lanyon 1998, Hsieh \& Turner 2001, Srinivasan et al. 2002). Overall, these animal studies have consistently indicated that mechanical loading influences the morphology of growing bone by increasing bone formation more than resorption. In humans, most evidence is derived from crosssectional observations. For instance, tennis players have been shown to have larger cortical thickness in the dominant playing arm compared with the nonplaying arm (Bass et al. 2002). Moreover, the increase in bone mass in elite gymnasts persists after retirement, suggesting that the beneficial effects of loading may induce lifelong benefits to bone strength (Bass et al. 1998). Similar findings have been obtained in a few longitudinal studies, reporting significant side-to-side differences in bone size and strength in tennis players 1.5-3 years after retirement (Haapasalo et al. 2000). However, the assumption that skeletal benefits obtained from exercise may be maintained into older age remains uncertain, as unequivocal longitudinal evidence is currently lacking. The timing and duration of exercise also influences the response to loading in humans. In fact, different responses to loading have been reported in pre-, peri-, and postpubertal tennis players. 


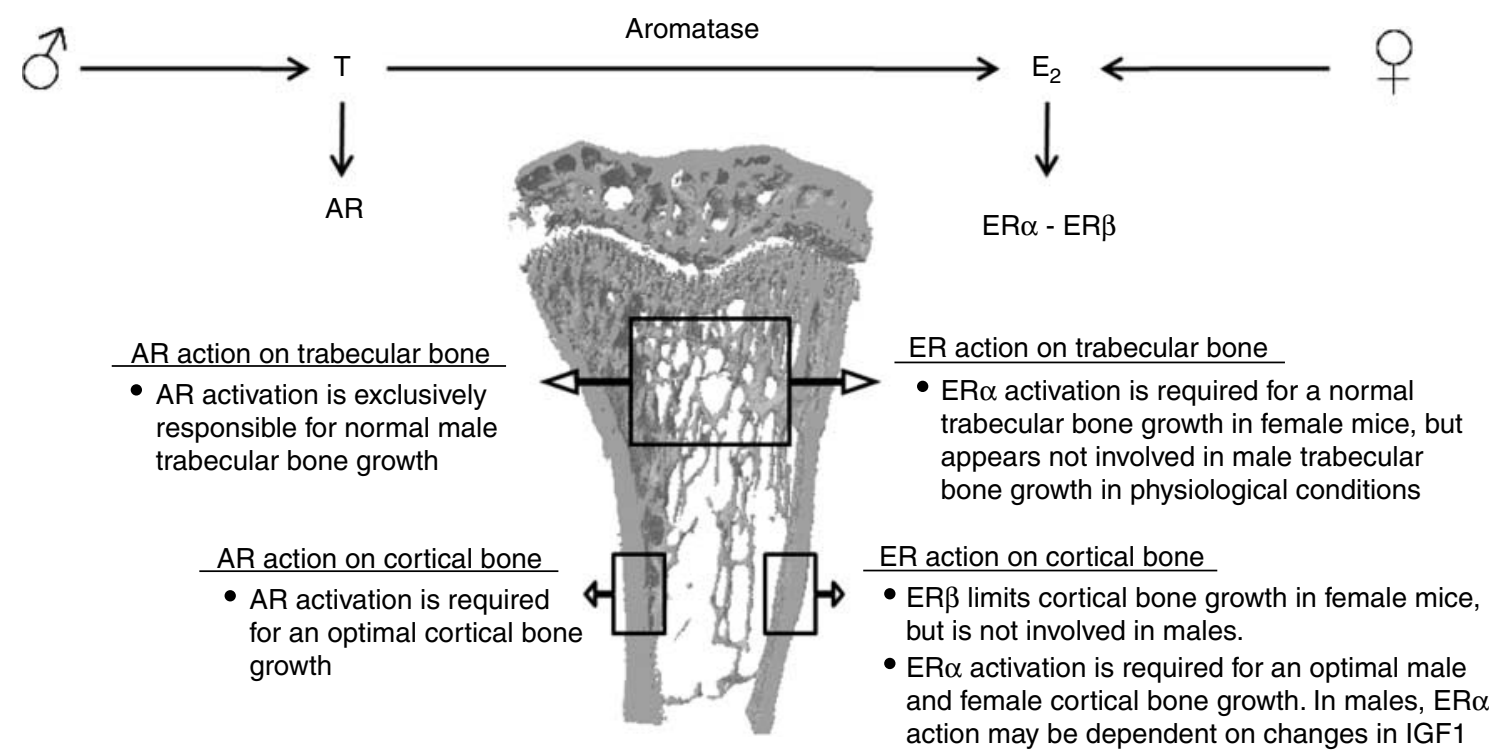

Figure 2 Differential roles of androgen receptor (AR) and estrogen receptor- $\alpha$ or $-\beta(E R \alpha$ or $-\beta$ ) signaling in the accrual of an optimal cortical and trabecular bone mass in male and female mice. $E_{2}, 17 \beta$-estradiol.

In female players, loading before puberty and during early puberty enhances periosteal bone formation and bone strength, whereas loading during late puberty bone is mainly accumulated at the endocortical bone surface without major changes in bone strength (Bass et al. 2002). In male players, on the other hand, periosteal expansion in response to loading is most pronounced in prepubertal and peripubertal boys and then tends to plateau (Ducher et al. 2009). It would seem therefore that pubertal growth and sex hormones appear to influence the adaptive response to exercise, and this interaction may be different in boys and girls.

\section{Interaction of sex steroids and mechanical loading}

Sex steroids may also modulate the response of bone to mechanical stimulation. This hypothesis originates from rodent studies, showing that female rats have more bone than male rats relative to body weight (Saville 1969, Wang et al. 2003). A study in human observed a similar evolution, as the increase in bone mass relative to muscle mass is greater in girls compared with boys during puberty (Schiessl et al. 1998), even after adjustment for fat mass (Ferretti et al. 1998). These observations suggest that estrogens alter the mechanosensitivity of bones, so that more bone is accumulated than is needed mechanically. Moreover, it has been hypothesized that estrogen withdrawal during menopause impairs the mechanically adaptive mechanism, and hereby contributes to postmenopausal bone loss and the development of osteoporosis (Lanyon \& Skerry 2001). Exercise, however, is generally believed to stimulate periosteal bone formation, whereas estrogen appears to have an inhibitory effect in females - at least in mice (Callewaert et al. 2010b). For instance, prepubertal female tennis players with low estrogen concentrations show a more favorable periosteal response compared to postpubertal girls with high estrogen levels (Bass et al. 2002). Concurrently, estrogen supplementation in male rats appears to suppress the periosteal response to mechanical loading (Saxon \& Turner 2006). According to in vitro as well as in vivo rodent studies, sex steroid signaling and mechanical loading may also share common signaling pathways. Estrogen and mechanical strain stimulate proliferation independently in osteoblast-like cells derived from male and female rats as well as in human osteoblast cells (Damien et al. 2000, Cheng et al. 2002). Nevertheless, ER modulators and antagonists block the increase in proliferation in response to mechanical strain, whereas dihydrotestosterone (DHT) and AR activation apparently are not involved. These findings suggest that ERs, but not AR, influence the response to strain. As a proof of this concept, periosteal bone formation in response to in vivo ulna loading is significantly reduced in female ER $\alpha \mathrm{KO}$ mice (Lee et al. 2003). In contrast, disruption of $E R \beta$ increases periosteal bone formation following loading in female but not in male mice (Saxon et al. 2007). Together, these findings clearly indicate that sex hormone signaling interferes with the mechanical response to loading, at least in female mice, with $\mathrm{ER} \alpha$ and ER $\beta$ having antagonistic effects. A recent report also investigated the role of sex steroid receptors in the mechanical sensitivity of the male skeleton (Callewaert et al. 2010c). This study suggests that ER $\alpha$ does not interfere with the adaptive response in males, which is in sharp contrast with the above-mentioned crucial role of $\mathrm{ER} \alpha$ in females. Indeed, periosteal bone formation is similarly increased following loading in male ER $\alpha \mathrm{KO}$ compared with wild-type mice. The apparent gender-dependent importance of $\mathrm{ER} \alpha$ in mice is also supported by observations in humans, since puberty and sex steroid exposure influence the mechanical bone response 


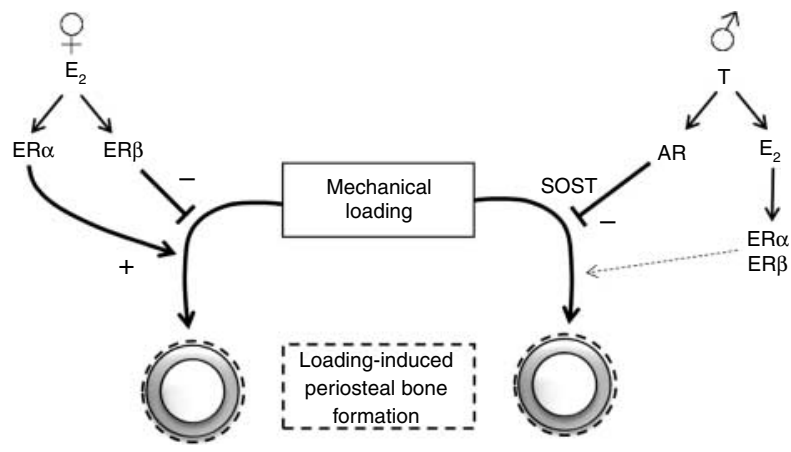

Figure 3 Interaction of sex steroids and their receptors with the adaptive response of bone to mechanical stimulation. In female mice, $E R \alpha$ activation is required for the full osteogenic response to loading, while ER $\beta$ activation inhibits it. In contrast, $E R \alpha$ or $E R \beta$ activation in male mice seems unimportant for an optimal response to mechanical stimulation. On the other hand, AR activation limits the mechanical sensitivity of the male skeleton, potentially through downregulation of SOST signaling. $E_{2}, 17 \beta$-estradiol; $E R \alpha$, estrogen receptor- $\alpha$; ER $\beta$, estrogen receptor- $\beta ; A R$, androgen receptor.

differently in boys and girls (Bass et al. 2002, Ducher et al. 2009). In addition, AR activation may even limit the response to mechanical stimulation, since AR deletion - both in the presence and absence of $E R \alpha$ - increases the periosteal bone response to loading (Callewaert et al. 2010c). AR signaling not only increases periosteal bone formation following loading, but also lowers SOST and sclerostin expression (Callewaert et al. 2010c). Sclerostin, which is encoded by the SOST gene, is the principal osteocyte-specific inhibitor of bone formation known to antagonize $\mathrm{Wnt} / \beta$-catenin signaling (Poole et al. 2005, ten Dijke et al. 2008). The role of osteocyte-specific sclerostin signaling in mechanotransduction has previously been demonstrated in both loading and unloading conditions (Robling et al. 2008, Lin et al. 2009). Therefore, AR signaling may interfere with the inhibiting effect of sclerostin signaling on bone formation. In conclusion, in vitro and in vivo animal data as well as observations in humans have indicated that estrogen may modulate the effects of loading in females. In fact, ER $\alpha$ activation is required for the full osteogenic response to loading, whereas ER $\beta$ activation appears to inhibit periosteal bone formation following loading in females. In contrast to female mice, ER $\alpha$ and ER $\beta$ apparently are not involved in the response to loading in male mice. AR signaling, on the other hand, limits the anabolic response to mechanical loading in male mice, possibly through interaction with sclerostin signaling (Fig. 3).

\section{Conclusion}

GH/IGF1 action, more than sex steroid action, appears to be the primary determinant of gender differences in pubertal bone growth, which, in turn, may be influenced by sex hormones (e.g. neonatal imprinting). Beside GH/IGF1, estrogens limit periosteal bone expansion but stimulate endocortical apposition in females. In males, both androgens and estrogens stimulate periosteal bone expansion and hence cortical bone growth during puberty. However, estrogen action on male cortical bone may at least partly be explained by concomitant changes in IGF1 (Fig. 1). In contrast with its role in cortical bone growth, AR activation alone is sufficient for the development of trabecular bone mass in males (Fig. 2). Finally, sex steroids and their receptors also have an impact on the mechanical sensitivity of the male and female skeleton. $\mathrm{AR}$ and ER $\beta$ signaling limit the osteogenic response to mechanical loading in male and female mice respectively. ER $\alpha$ activation, on the other hand, stimulates bone formation in response to mechanical loading in female but not male mice (Fig. 3). Therefore, skeletal sexual dimorphism is not only determined by androgen action in males and estrogen action in females respectively but also by complex genderand time-specific interactions between sex hormones, GH-IGF1, and mechanical loading.

\section{Declaration of interest}

The authors declare that there is no conflict of interest that could be perceived as prejudicing the impartiality of the research reported.

\section{Funding}

This review was supported by grants OT/05/53 and OT/09/035 from the Catholic University Leuven (K U Leuven) and grant G.0605.07 from the Fund for Scientific Research Flanders, Belgium (F W O-Vlaanderen).

\section{Acknowledgements}

$\mathrm{S}$ Boonen is a senior clinical investigator of the Fund for Scientific Research (FWO-Vlaanderen) and holder of the Leuven University Chair in Gerontology and Geriatrics. D Vanderschueren is a senior clinical investigator of the Leuven University Hospital Clinical Research Fund.

\section{References}

Bass S, Pearce G, Bradney M, Hendrich E, Delmas PD, Harding A \& Seeman E 1998 Exercise before puberty may confer residual benefits in bone density in adulthood: studies in active prepubertal and retired female gymnasts. Journal of Bone and Mineral Research 13 500-507. (doi:10.1359/ jbmr.1998.13.3.500)

Bass SL, Saxon L, Daly RM, Turner CH, Robling AG, Seeman E \& Stuckey S 2002 The effect of mechanical loading on the size and shape of bone in pre-, peri-, and postpubertal girls: a study in tennis players. Journal of Bone and Mineral Research 17 2274-2280. (doi:10.1359/jbmr.2002.17.12.2274)

Boonen S, Kaufman JM, Goemaere S, Bouillon R \& Vanderschueren D 2007 The diagnosis and treatment of male osteoporosis: defining, assessing, and preventing skeletal fragility in men. European Journal of Internal Medicine $\mathbf{1 8}$ 6-17. (doi:10.1016/j.ejim.2006.09.005)

Borjesson A, Lagerquist M, Liu C, Shao R, Windahl S, Karlsson C, Sjogren K, Moverare-Skrtic S, Antal M, Krust A et al. 2010 The role of estrogen receptor-alpha in growth plate cartilage for longitudinal bone growth. Journal of Bone and Mineral Research. In press. (doi:10.1002/jbmr.156) 
Bouillon R, Bex M, Vanderschueren D \& Boonen S 2004 Estrogens are essential for male pubertal periosteal bone expansion. Journal of Clinical Endocrinology and Metabolism 89 6025-6029. (doi:10.1210/jc.2004-0602)

Callewaert F, Venken K, Ophoff J, De Gendt K, Torcasio A, van Lenthe GH, Van Oosterwyck H, Boonen S, Bouillon R, Verhoeven G et al. 2009 Differential regulation of bone and body composition in male mice with combined inactivation of androgen and estrogen receptor-alpha. FASEB Journal 23 232-240. (doi:10.1096/fj.08-113456)

Callewaert F, Boonen S \& Vanderschueren D 2010a Sex steroids and the male skeleton: a tale of two hormones. Trends in Endocrinology and Metabolism 21 89-95. (doi:10.1016/j.tem.2009.09.002)

Callewaert F, Venken K, Kopchick J, Torcasio A, van Lenthe GH, Boonen S \& Vanderschueren D 2010b Sexual dimorphism in cortical bone size and strength but not density is determined by independent and time-specific actions of sex steroids and IGF-I: evidence from pubertal mouse models. Journal of Bone and Mineral Research 25 617-626. (doi:10.1359/jbmr.090828)

Callewaert F, Bakker A, Schrooten J, Van Meerbeek B, Verhoeven G, Boonen S \& Vanderschueren D 2010c Androgen receptor disruption increases the osteogenic response to mechanical loading in male mice. Journal of Bone and Mineral Research 25 124-131. (doi:10.1359/jbmr.091001)

Cheng MZ, Rawlinson SC, Pitsillides AA, Zaman G, Mohan S, Baylink DJ \& Lanyon LE 2002 Human osteoblasts' proliferative responses to strain and 17 beta-estradiol are mediated by the estrogen receptor and the receptor for insulin-like growth factor I. Journal of Bone and Mineral Research 17 593-602. (doi:10.1359/jbmr.2002.17.4.593)

Damien E, Price JS \& Lanyon LE 2000 Mechanical strain stimulates osteoblast proliferation through the estrogen receptor in males as well as females. Journal of Bone and Mineral Research 15 2169-2177. (doi:10.1359/jbmr.2000. 15.11.2169)

ten Dijke P, Krause C, de Gorter DJ, Lowik CW \& van Bezooijen RL 2008 Osteocyte-derived sclerostin inhibits bone formation: its role in bone morphogenetic protein and Wnt signaling. Journal of Bone and Joint Surgery. American Volume 90 31-35. (doi:10.2106/JBJS.G.01183)

Ducher G, Daly R \& Bass S 2009 The effects of repetitive loading on bone mass and geometry in young male tennis players: a quantitative study using magnetic resonance imaging. Journal of Bone and Mineral Research $\mathbf{2 4}$ 1686-1692. (doi:10.1359/jbmr.090415)

Ferretti JL, Capozza RF, Cointry GR, Garcia SL, Plotkin H, Alvarez Filgueira ML \& Zanchetta JR 1998 Gender-related differences in the relationship between densitometric values of whole-body bone mineral content and lean body mass in humans between 2 and 87 years of age. Bone 22 683-690. (doi:10.1016/S8756-3282(98)00046-5)

Finkelstein JS, Klibanski A, Neer RM, Doppelt SH, Rosenthal DI, Segre GV \& Crowley WF Jr 1989 Increases in bone density during treatment of men with idiopathic hypogonadotropic hypogonadism. Journal of Clinical Endocrinology and Metabolism 69 776-783. (doi:10.1210/jcem-69-4-776)

Frost HM 2003 Bone's mechanostat: a 2003 update. Anatomical Record. Part A, Discoveries in Molecular, Cellular, and Evolutionary Biology 275 1081-1101. (doi:10.1002/ar.a.10119)

Garn S 1970 The earlier gain and later loss of cortical bone, in nutritional perspective, pp 3-120. Springfield, Ill: Charles C. Thomas.

Gilsanz V, Boechat MI, Gilsanz R, Loro ML, Roe TF \& Goodman WG 1994 Gender differences in vertebral sizes in adults: biomechanical implications. Radiology 190 678-682.

Haapasalo H, Kontulainen S, Sievanen H, Kannus P, Jarvinen M \& Vuori I 2000 Exercise-induced bone gain is due to enlargement in bone size without a change in volumetric bone density: a peripheral quantitative computed tomography study of the upper arms of male tennis players. Bone 27 351-357. (doi:10.1016/S8756-3282(00)00331-8)

Hsieh YF \& Turner CH 2001 Effects of loading frequency on mechanically induced bone formation. Journal of Bone and Mineral Research 16 918-924. (doi:10.1359/jbmr.2001.16.5.918)

Iuliano-Burns S, Hopper J \& Seeman E 2009 The age of puberty determines sexual dimorphism in bone structure: a male/female co-twin control study. Journal of Clinical Endocrinology and Metabolism 94 1638-1643. (doi:10.1210/ jc.2008-1522)
Jansson JO, Ekberg S, Isaksson O, Mode A \& Gustafsson JA 1985 Imprinting of growth hormone secretion, body growth, and hepatic steroid metabolism by neonatal testosterone. Endocrinology 117 1881-1889. (doi:10.1210/endo-117-5-1881)

Juul A 2001 The effects of oestrogens on linear bone growth. Human Reproduction Update 7 303-313. (doi:10.1093/humupd/7.3.303)

Kawano H, Sato T, Yamada T, Matsumoto T, Sekine K, Watanabe T, Nakamura T, Fukuda T, Yoshimura K, Yoshizawa Tet al. 2003 Suppressive function of androgen receptor in bone resorption. PNAS 100 9416-9421. (doi:10.1073/pnas.1533500100)

Khosla S, Amin S \& Orwoll E 2008 Osteoporosis in men. Endocrine Reviews 29 441-464. (doi:10.1210/er.2008-0002)

Kirmani S, Christen D, van Lenthe GH, Fischer PR, Bouxsein ML, McCready LK, Melton LJ III, Riggs BL, Amin S, Muller R et al. 2009 Bone structure at the distal radius during adolescent growth. Journal of Bone and Mineral Research 24 1033-1042. (doi:10.1359/jbmr.081255)

Lanyon L \& Skerry T 2001 Postmenopausal osteoporosis as a failure of bone's adaptation to functional loading: a hypothesis. Journal of Bone and Mineral Research 16 1937-1947. (doi:10.1359/jbmr.2001.16.11.1937)

Laron Z 1999 The essential role of IGF-I: lessons from the long-term study and treatment of children and adults with Laron syndrome. Journal of Clinical Endocrinology and Metabolism 84 4397-4404. (doi:10.1210/jc.84.12.4397)

Lee K, Jessop H, Suswillo R, Zaman G \& Lanyon L 2003 Endocrinology: bone adaptation requires oestrogen receptor-alpha. Nature $\mathbf{4 2 4} 389$. (doi: 10.1038/424389a)

Leger J, Mercat I, Alberti C, Chevenne D, Armoogum P, Tichet J \& Czernichow P 2007 The relationship between the GH/IGF-I axis and serum markers of bone turnover metabolism in healthy children. European Journal of Endocrinology 157 685-692. (doi:10.1530/EJE-07-0402)

Lin C, Jiang X, Dai Z, Guo X, Weng T, Wang J, Li Y, Feng G, Gao X \& He L 2009 Sclerostin mediates bone response to mechanical unloading via antagonizing Wnt/beta-catenin signaling. Journal of Bone and Mineral Research 24 1651-1661. (doi:10.1359/jbmr.090411)

Lindberg MK, Alatalo SL, Halleen JM, Mohan S, Gustafsson JA \& Ohlsson C 2001 Estrogen receptor specificity in the regulation of the skeleton in female mice. Journal of Endocrinology 171 229-236. (doi:10.1677/joe.0. 1710229)

Lupu F, Terwilliger JD, Lee K, Segre GV \& Efstratiadis A 2001 Roles of growth hormone and insulin-like growth factor 1 in mouse postnatal growth. Developmental Biology 229 141-162. (doi:10.1006/dbio.2000.9975)

Mauras N, Rogol AD, Haymond MW \& Veldhuis JD 1996 Sex steroids, growth hormone, insulin-like growth factor-1: neuroendocrine and metabolic regulation in puberty. Hormone Research 45 74-80. (doi:10.1159/000184763)

Mauras N, O’Brien KO, Klein KO \& Hayes V 2000 Estrogen suppression in males: metabolic effects. Journal of Clinical Endocrinology and Metabolism 85 2370-2377. (doi:10.1210/jc.85.7.2370)

Miyaura C, Toda K, Inada M, Ohshiba T, Matsumoto C, Okada T, Ito M, Shizuta Y \& Ito A 2001 Sex- and age-related response to aromatase deficiency in bone. Biochemical and Biophysical Research Communications 280 1062-1068. (doi:10.1006/bbrc.2001.4246)

Mosley JR \& Lanyon LE 1998 Strain rate as a controlling influence on adaptive modeling in response to dynamic loading of the ulna in growing male rats. Bone 23 313-318. (doi:10.1016/S8756-3282(98)00113-6)

Mosley JR, March BM, Lynch J \& Lanyon LE 1997 Strain magnitude related changes in whole bone architecture in growing rats. Bone 20 191-198. (doi:10.1016/S8756-3282(96)00385-7)

Poole KE, van Bezooijen RL, Loveridge N, Hamersma H, Papapoulos SE, Lowik CW \& Reeve J 2005 Sclerostin is a delayed secreted product of osteocytes that inhibits bone formation. FASEB Journal 19 1842-1844. (doi:10.1096/fj.05-4221fje)

Riggs BL, Khosla S \& Melton LJ III 2002 Sex steroids and the construction and conservation of the adult skeleton. Endocrine Reviews 23 279-302. (doi:10.1210/er.23.3.279)

Robling AG, Niziolek PJ, Baldridge LA, Condon KW, Allen MR, Alam I, Mantila SM, Gluhak-Heinrich J, Bellido TM, Harris SE et al. 2008 Mechanical stimulation of bone in vivo reduces osteocyte expression of Sost/sclerostin. Journal of Biological Chemistry 283 5866-5875. (doi:10.1074/ jbc.M705092200) 
Rochira V, Zirilli L, Madeo B, Aranda C, Caffagni G, Fabre B, Montangero VE, Roldan EJ, Maffei L \& Carani C 2007 Skeletal effects of long-term estrogen and testosterone replacement treatment in a man with congenital aromatase deficiency: evidences of a priming effect of estrogen for sex steroids action on bone. Bone 40 1662-1668. (doi:10.1016/j.bone.2007.01.022)

Saville PD 1969 Changes in skeletal mass and fragility with castration in the rat; a model of osteoporosis. Journal of the American Geriatrics Society 17 155-166.

Saxon LK \& Turner CH 2006 Low-dose estrogen treatment suppresses periosteal bone formation in response to mechanical loading. Bone 39 1261-1267. (doi:10.1016/j.bone.2006.06.030)

Saxon LK, Robling AG, Castillo AB, Mohan S \& Turner CH 2007 The skeletal responsiveness to mechanical loading is enhanced in mice with a null mutation in estrogen receptor-beta. American Journal of Physiology. Endocrinology and Metabolism 293 E484-E491. (doi:10.1152/ajpendo.00189.2007)

Schiessl H, Frost HM \& Jee WS 1998 Estrogen and bone-muscle strength and mass relationships. Bone 22 1-6. (doi:10.1016/S8756-3282(97)00223-8)

Seeman E 2001 Clinical review 137: sexual dimorphism in skeletal size, density, and strength. Journal of Clinical Endocrinology and Metabolism 86 4576-4584. (doi:10.1210/jc.86.10.4576)

Seeman E 2002 Pathogenesis of bone fragility in women and men. Lancet 359 1841-1850. (doi:10.1016/S0140-6736(02)08706-8)

Sims NA, Clement-Lacroix P, Da Ponte F, Bouali Y, Binart N, Moriggl R, Goffin V, Coschigano K, Gaillard-Kelly M, Kopchick J et al. 2000 Bone homeostasis in growth hormone receptor-null mice is restored by IGF-I but independent of Stat5. Journal of Clinical Investigation 106 1095-1103. (doi:10.1172/JCI10753)

Sims NA, Dupont S, Krust A, Clement-Lacroix P, Minet D, Resche-Rigon M, Gaillard-Kelly M \& Baron R 2002 Deletion of estrogen receptors reveals a regulatory role for estrogen receptors-beta in bone remodeling in females but not in males. Bone 30 18-25. (doi:10.1016/S8756-3282(01)00643-3)

Sims NA, Clement-Lacroix P, Minet D, Fraslon-Vanhulle C, Gaillard-Kelly M, Resche-Rigon M \& Baron R 2003 A functional androgen receptor is not sufficient to allow estradiol to protect bone after gonadectomy in estradiol receptor-deficient mice. Journal of Clinical Investigation 111 1319-1327. (doi:10.1172/JCI17246)

Sims NA, Brennan K, Spaliviero J, Handelsman DJ \& Seibel MJ 2006 Perinatal testosterone surge is required for normal adult bone size but not for normal bone remodeling. American Journal of Physiology. Endocrinology and Metabolism 290 E456-E462. (doi:10.1152/ajpendo.00311.2005)

Smith EP, Boyd J, Frank GR, Takahashi H, Cohen RM, Specker B, Williams TC, Lubahn DB \& Korach KS 1994 Estrogen resistance caused by a mutation in the estrogen-receptor gene in a man. New England Journal of Medicine 331 1056-1061. (doi:10.1056/NEJM199410203311604)

Smith EP, Specker B, Bachrach BE, Kimbro KS, Li XJ, Young MF, Fedarko NS, Abuzzahab MJ, Frank GR, Cohen RM et al. 2008 Impact on bone of an estrogen receptor-alpha gene loss of function mutation. Journal of Clinical Endocrinology and Metabolism 93 3088-3096. (doi:10.1210/jc.2007-2397)

Srinivasan S, Weimer DA, Agans SC, Bain SD \& Gross TS 2002 Lowmagnitude mechanical loading becomes osteogenic when rest is inserted between each load cycle. Journal of Bone and Mineral Research 17 1613-1620. (doi:10.1359/jbmr.2002.17.9.1613)
Turner RT, Wakley GK \& Hannon KS 1990 Differential effects of androgens on cortical bone histomorphometry in gonadectomized male and female rats. Journal of Orthopaedic Research 8 612-617. (doi:10.1002/jor. 1100080418)

Vandenput L, Ederveen AG, Erben RG, Stahr K, Swinnen JV, Van Herck E, Verstuyf A, Boonen S, Bouillon R \& Vanderschueren D 2001 Testosterone prevents orchidectomy-induced bone loss in estrogen receptor-alpha knockout mice. Biochemical and Biophysical Research Communications 285 70-76. (doi:10.1006/bbrc.2001.5101)

Vanderschueren D, van Herck E, Nijs J, Ederveen AG, De Coster R \& Bouillon R 1997 Aromatase inhibition impairs skeletal modeling and decreases bone mineral density in growing male rats. Endocrinology 138 2301-2307. (doi:10.1210/en.138.6.2301)

Vanderschueren D, Vandenput L, Boonen S, Lindberg MK, Bouillon R \& Ohlsson C 2004 Androgens and bone. Endocrine Reviews 25 389-425. (doi:10.1210/er.2003-0003)

Venken K, Schuit F, Van Lommel L, Tsukamoto K, Kopchick JJ, Coschigano K, Ohlsson C, Moverare S, Boonen S, Bouillon R et al. 2005 Growth without growth hormone receptor: estradiol is a major growth hormoneindependent regulator of hepatic insulin-like growth factor-I synthesis. Journal of Bone and Mineral Research 20 2138-2149. (doi:10.1359/JBMR. 050811)

Venken K, De Gendt K, Boonen S, Ophoff J, Bouillon R, Swinnen JV, Verhoeven G \& Vanderschueren D 2006 Relative impact of androgen and estrogen receptor activation in the effects of androgens on trabecular and cortical bone in growing male mice: a study in the androgen receptor knockout mouse model. Journal of Bone and Mineral Research 21 576-585. (doi:10.1359/jbmr.060103)

Vidal O, Lindberg MK, Hollberg K, Baylink DJ, Andersson G, Lubahn DB, Mohan S, Gustafsson JA \& Ohlsson C 2000 Estrogen receptor specificity in the regulation of skeletal growth and maturation in male mice. PNAS 97 5474-5479. (doi:10.1073/pnas.97.10.5474)

Wang L, McMahan CA, Banu J, Okafor MC \& Kalu DN 2003 Rodent model for investigating the effects of estrogen on bone and muscle relationship during growth. Calcified Tissue International 72 151-155. (doi:10.1007/ s00223-001-1122-y)

Windahl SH, Vidal O, Andersson G, Gustafsson JA \& Ohlsson C 1999 Increased cortical bone mineral content but unchanged trabecular bone mineral density in female ERbeta $(-/-)$ mice. Journal of Clinical Investigation 104 895-901. (doi:10.1172/JCI6730)

Zamberlan N, Radetti G, Paganini C, Gatti D, Rossini M, Braga V \& Adami S 1996 Evaluation of cortical thickness and bone density by roentgen microdensitometry in growing males and females. European Journal of Pediatrics 155 377-382. (doi:10.1007/BF01955265)

\section{Received in final form 11 August 2010 \\ Accepted 31 August 2010}

Made available online as an Accepted Preprint 31 August 2010 